Collection: EFI 2008 Annual Conference Week - Orvieto (Italy)

Adaptation of Forest Landscape to Environmental Changes

Guest Editor: Giuseppe Scarascia Mugnozza (CRA - Rome, Italy)

\title{
Adaptation of forest landscape to environmental changes
}

\section{Scarascia-Mugnozza G ${ }^{(1-2)}$}

The 2008 Scientific Seminar of the European Forest Institute was held in Orvieto (Italy) in September 18-20, with the aim of improving the knowledge and exchange of research results in the following fields: (1) relationship between ecological functions (productivity, biogeochemical cycles, genetic biodiversity) at the landscape scale; (2) landscape management tools for environmental amelioration and restoration as planting trees, forest and agroforestry, that are also relevant for the agro-environmental measures of the New Agricultural Policy of the EU and Forest Action Plan; (3) valuation of various forest-related functions, with special emphasis on forest tourism.

Keywords: Ecological functions, Landascape management, Agroforestry, Forest tourism

Historically, man has profoundly modified the natural environment producing finely grained combinations of different types of rural land uses, varying from intensively cultivated fields to natural tree and shrubs communities, generally referred to with the term of landscape. The creation of a spatial heterogeneity made of a mosaic of forest patches, the presence of different stand age classes, the implementation of contact or transition zones among contrasting ecosystems, the formation of corridors made by linear belts of trees and hedges also utilized for timber and biomass production, are all conditions that favour environmental variability and, therefore, biological diversity. Many of these forest management aspects should be analysed and solved at the landscape level, and may have important consequences on different, but crucial, economic activities as, e.g., tourism. The need to combine in a landscape the production of timber and biomass with environmental and cultural services, parallels the necessity of making the landscape conservation objective an economically sustainable endeavour for forest owners and agro-forestry farmers.

Forest research contributes to this important task by developing an array of tools, ranging from landscape analysis and planning to providing the best plant material and cultivation systems for high quality and quantity ligno-cellulosic biomass production, to identifying the most appropriate socioeconomic initiatives to make tree and forest management an economically and environmentally viable activity. This need is particularly evident in the Mediterranean basin where certain regions have only isolated forest patches where their management of wildlife and of biodiversity, and the adaptation of plants and animals to environmental changes are impaired. Therefore, the management needs to be integrated across the whole landscape rather than related to isolated landscape segments.

The 2008 Scientific Seminar of the European Forest Institute was held in Orvieto, Italy, in September 18-20, with the aim to improve the knowledge and exchange of research results in the following fields:

- relationship between ecological functions (productivity, biogeochemical cycles, genetic biodiversity) at the landscape scale;

- landscape management tools for environmental amelioration and restoration as planting trees, forest and agroforestry, that are also relevant for the agro-environmental measures of the New Agricultural Policy of the EU and Forest Action Plan;

- valuation of various forest-related functions, with special emphasis on forest tourism.

The Seminar witnessed the participation of
(1) Consiglio per la Ricerca e Sperimentazione in Agricoltura (C.R.A.), Dipartimento Agronomia, Foreste e Territorio, v. Nazionale 82, I-00184 Roma (Italy); (2) Dipartimento di Scienze dell'Ambiente Forestale e delle sue Risorse (Di.S.A.F.Ri.), University of Tuscia, v. S. Camillo de' Lellis snc, I-01100 Viterbo (Italy)

\section{(a) Giuseppe Scarascia-Mugnozza (giuseppe.scarascia@entecra.it)}

Received: Jul 24, 2009 - Accepted: Jul 28, 2009

Citation: Scarascia-Mugnozza G, 2009. Adaptation of forest landscape to environmental changes. iForest 2: 127 [online: 2009-07-30] URL:

http://www.sisef.it/iforest/show.php? id $=509$

more than 200 scientists from Europe and outside, particularly form the Mediterranean region as it was co-organized by EFIMED, the EFI Regional Office fro the Mediterranean area and by the working group IUFRO 4.2 .00 on forest inventory and and planning. The first group of papers presented at the Scientific Seminar are published in the current volume of iForest - Biogeosciences and Forestry (see Collection: EFI 2008 Annual Conference Week), after a full, peer-review open process.

\section{Author's Box}

Giuseppe Scarascia-Mugnozza is full professor of Silviculture and Forest Ecophysiology at the University of Tuscia (Viterbo), and heads the Department of Agronomy, Forestry and Land Use of the Italian Research Council for Agriculture (C.R.A.). Coordinator of the EU Large Infrastructure POP/EUROFACE and partner of several EU research projects, member of the Scientific Council of the EU-Forest Technology Platform, national delegate and vice-chair of the ESF-COST Domain "Forests, their Products and Services" and member of the LESC (Life and environmental sciences) Committee of the European Science Foundation. 